\title{
Some Thoughts on Decolonisation, Decoloniality, Racism, and Challenges of Citizenship in Communities of Learning
}

\section{Lewis R. Gordon \\ ORCID iD: https://orcid.org/0000-0002-4124-1340}

\begin{abstract}
This article is an examination of challenges posed by decolonial theory for communities of learning in societies in which racism is pervasive. As racism is also an inheritance of colonialism, it draws sustenance from institutions developed for the efficiency and flourishing of colonial practices of disempowerment. Universities are among those institutions. Decolonial responses are dedicated to decolonising everything from curricula to interactions between universities and the wider community and across staff, students, faculty, and administrators. The author explores, critically, some of the metatheoretical debates that distinguish decoloniality from decolonisation in this process that often their ironic impact on expanding the norms of academic norms, in market forms, to the wider society through academic publishing and varieties of social media.
\end{abstract}

Keywords: decolonisation, decoloniality, epistemic closure, pedagogical imperative, political responsibility, racism, university

\section{Introduction}

This discussion examines the challenges that decolonial theory poses for communities of learning and the impact of racism as a political phenomenon of disempowerment. Many universities have become battlefields, so to speak, in which discourses and struggles for decolonisation occur. These efforts are often marked by the avowed practice - or praxis, if we will - of decolonising 
everything from curricula to interactions with one another in an order of hierarchies. The roles and structures under contestation range from administrations and faculty to both and students, faculty and students, all the above and staff, and the relationship of the entire constellation to the downtrodden in the rest of society. Amid all this is also the set of metatheoretical debates in which some theorists differentiate decoloniality from decolonisation. These conflicts lead to a form of battle before the battle or struggle onto the struggle in locations of contestation outside of the university but whose consequence is part of academic markets - namely, journals, publishing houses, online forums, and varieties of media ${ }^{1}$. For those confused at this point, decolonialists distinguish themselves from agents of decolonisation through the question of the object of their practice. Whereas many against decolonisation focus on dismantling vestiges of colonialism, decolonialists argue that more is needed to be done because colonialism produced modes of colonial ways of being in the world. They call this 'coloniality'.

One could formally dismantle colonial states through practices of decolonisation but then find oneself living in what today is called the 'after life' of colonialism in the form of continued coloniality, which some call 'the coloniality of being'. The practices and theorising that are antidotes to such problematic modes of being are, they argue, decoloniality ${ }^{2}$. Curiously, a result of both decolonising and decoloniality is a search for practices of disentanglement similar in form to poststructuralist arguments of the late 1980s

${ }^{1}$ Studies are many. See A. Kayum Ahmed's dissertation, The Rise of Fallism: \#RhodesMustFall and the Movement to Decolonize the University, Columbia University Dissertation (2019), which offers a fairly comprehensive bibliography through discussion of the South African and United Kingdom contexts and the inspiration they also drew from African American and Latin American thought.

${ }^{2}$ In addition to Ahmed's The Rise of Fallism (2019), see also his, 'On Black Pain/Black Liberation and the Rise of Fallism' in Black Issues in Philosophy (March 19, 2019). https://blog.apaonline.org/2019/03/19/on-black-pain-blackliberation-and-the-rise-of-fallism/; as well as Walter Mignolo and Catherine Walsh's On Decoloniality: Concepts, Analytics, Praxis (2018); and Sayan Dey's edited, Different Spaces, Different Voices: A Rendezvous with Decoloniality (2018). 
into the end of the 20th century about persisting orders of knowledge and practices that produce subjugated subjectivities or subjects. As Judith Butler (1990) had argued against discourses premised upon attachments to subjects, exorcisms of discourses through which coloniality fosters and festers must strike many theorists who went through those old debates with a sense of eternal return.

There are, however, differences as decolonial forms of arguments point, at least, to the Global South as the origins of their reflections, primarily through the critical thought of initial dependency and then anti-Eurocentric thought from Samir Amin (1988) to Aníbal Quijano (1995; 2000) and then, through varieties of mediations from Enrique Dussel $(1996 ; 2013)$ to Walter Mignolo (2018), Ramón Grosfoguel (2013; 2012), Nelson Maldonado-Torres (2016; 2008; 2007), Maria Lugones (2010; 2008), Catherine Walsh (2018), and varieties of recent proponents such as Sabelo Ndlovu-Gatsheni (2013) in South Africa $^{3}$. Each of these thinkers come to this discussion from very different disciplines - for example, Economics, Philosophy, Literature, Sociology, Religion, Philosophy, Critical Pedagogy and Education, and more, which makes at least the discourse of decoloniality a transdisciplinary one. Yet my observation of at least the poststructural form raises the question of which kind of poststructuralism, structuralism, or other kind of theory is manifested here. After all, decolonial theorists could legitimately argue, for the sake of consistency, that poststructuralism is an exemplification of coloniality, which would make at least any effort to subsume their thought under such a rubric an example of coloniality. I would like to stress in responses that I am not arguing here that poststructuralism or any other kind of Euro-animated theory would in any way legitimate decolonial theory. My claim here is simply that the form decolonial arguments take maps neatly onto poststructuralist thought.

Poststructuralist thought took many forms in the second half of the 20th century as its proponents responded to varieties of structuralism and other forms of knowledge in the Euromodern academy ${ }^{4}$. I will not get into the details

${ }^{3}$ As many of the others are included in the texts in the preceding notes, I here add Sabelo Ndlovu-Gatsheni's work in this note: Coloniality of Power in Postcolonial Africa: Myths of Decolonization (2013).

${ }^{4}$ For a historical philosophical overview of structuralism, poststructuralism, and the implications and misunderstandings of both, see Peter Caws, Structuralism: A Philosophy for the Human Sciences (1997). For critical 
here of the distinction between structuralism and poststructuralism, since unfortunately many poststructuralists are often unaware of their arguments either being poststructural or structural. Many often simply assert their thought as 'theory'. What structuralism and poststructuralism share is an understanding of the importance of 'discourse'. This activity - which one could also call 'performance' and 'performativity' - is enacted through the production of rules and of rules about rules through which whatever is under critique acquires 'intelligibility'. The structuralists are often unwilling to say in advance what may become manifested from such critique, whereas poststructuralists are often willing to declare in advance their rejection of essence, essentialism, grand narratives, subjects, binaries, and a plethora of other intellectual commitments through which oppressive practices are sustained. Along the way, poststructuralism takes form in varieties of theoretical movements ranging from semiological psychoanalysis to textual critiques, of which Deconstruction is the most famous exemplar, archaeologies of epistemes (sciences) and other forms of gnosis (knowledges) practices, and genealogical unveiling of relations of power at the heart of discourses in the form of power/knowledge or knowledge/power.

At the level of metatheory - that is, theory about theory - however, important conundrums do arise. Critics have shown, for instance, that there is not only poststructuralist essentialist anti-essentialism but also poststructuralist Eurocentrism at the heart of how poststructuralist critique of Eurocentrism tends to equate theory itself with European thought ${ }^{5}$. In other words, it does

discussions connected to the context of the Global South, see Lewis R. Gordon, Her Majesty's Other Children: Sketches of Racism in a Neocolonial Age (1997), Chapter 5; Lewis R. Gordon, Disciplinary Decadence: Living Thought in Trying Times (2006); and also by Lewis R. Gordon, Freedom, Justice, and Decolonization (2021).

${ }^{5}$ See Paget Henry, Caliban's Reason: Introducing Afro-Caribbean Philosophy (2000) and Paget Henry, 'C.L.R. James and the Orthodoxies of John McClendon and David Scott: A Review Essay' (2007: 185-186); Eric Nelson, Chinese and Buddhist Philosophy in Early Twentieth-Century German Thought (2017); Lewis R. Gordon, Her Majesty's Other Children (1997); Disciplinary Decadence (2006); and the discussion of such debates along the concerns of interpellation in An Introduction to Africana Philosophy (2008), and 'Essentialist Anti-Essentialism, with Considerations from Other Sides of 
not take much to realise that almost exclusively arguing against Eurocentrism through discussing European thinkers results in maintaining European thought at the centre of thought. There is, as well, the political critique, where some proponents, in seeing poststructuralism as liberatory - as in fact the emancipatory exemplification of theory's potential - had to account for the flourishing of influence and professional rewards of such forms of thought in hegemonic centres of the dreaded neoliberal academy. It is not only Marxists but also Black liberationists who evoke the spirit of Malcolm X, who would raise the special relationship poststructuralist stars have with wealthy foundations of the establishment as a cause for proverbial pause ${ }^{6}$.

As the unfortunate damned of the earth wallow in more radicalised inequalities, the distance between them and the theorists who focused on discourse has increased. Yet the market commodification of knowledge did not rest, and as others hoped to transform their thought into capital from that model, rebranding became the order of the day. Thus, textual poststructuralism is now 'critical theory'. This is distinct from the Frankfurt School critical theory, which examined problems raised from Kant through to Hegel with social-theoretical analysis from Marx, Weber, and Freud. Genealogical poststructuralism, in contrast, sought more fertile soil along the so-called periphery. A combination of textual poststructuralism and genealogical poststructuralism, with some of the ideas from Black feminist thought and Black existentialism, is now offered under the brand of 'Afropessimism'. The genealogical turn was already there in the analysis of coloniality and the move to decoloniality, and elements from varieties of Indigenous and Black thought also came to the fore in what is now often offered as decolonial thought ${ }^{7}$. Now, my interest here is not to reject or support these movements. It is already clear to me, for instance, that a clear distinction between what is now called 'critical theory' on the one hand and what are called 'Afropessimism' and 'decolonial theory' on the other is easily seen in their audiences. The former speaks almost exclusively to a white, elite academy with at times tokenistic representations of colour. The latter are attractive to varieties of academics and activists in the

Modernity' (2012).

${ }^{6}$ I discussed some of these back in 1997 in Her Majesty's Other Children. See also Aijaz Ahmad, In Theory: Classes, Nations, and Literatures (1992).

${ }^{7}$ For elaboration, see Lewis R. Gordon, Freedom, Justice, and Decolonization (2021). 
Global South ${ }^{8}$. Thus, whether one disagrees with the latter on theoretical grounds, something is at work with such clear demographical difference, even where for the most part the practitioners of all three may be distanced from those suffering material forces of inequality in an age of information receiving more priority than experiences (also a contested term) and degradations of esteem and flesh. As most of the action inevitably coalesces around institutions of learning, I will now offer some thoughts about the virtues of education and schools that may be worth considering as additions to these debates. The focus on these institutions makes sense, after all, since many of their functionaries act under the assumption of their independence even during times of declared colonialism. If independent, why should educational institutions change in postcolonial times or postcolonies?

\section{A Community of Learners}

We have already touched on the answer to that question in the ideas of neocolonial institutions and coloniality. So, let us instead move to the idea of these institutions, imagined or otherwise, before at least Euromodern colonisation of much of the planet. In English we speak of the 'university', which is very different from how many ancient peoples and those in other languages and cultures today understand places of learning. As the Englishspeaking institutions are heavily influenced by a Greco-Latin past, let us begin with those, although I by no means want to affirm the fallacy of claiming that

${ }^{8}$ Readers for whom this may not seem evident should consult A. Kyum Ahmed's dissertation and 'On Black Pain/Black Liberation and the Rise of Fallism', which documents the audiences across social media in Africa and Europe; and Catherine Walsh's analysis of the role of indigenous activists in articulating more recent exemplifications of decolonial thought, brings those audiences to the fore. See her, 'The Decolonial For: Resurgences, Shifts, and Movements', in Walter Mignolo and Catherine Walsh, On Decoloniality: Concepts, Analytics, Praxis (2018: 15-32). And, for a discussion of concerns of textualism from perspectives of black thought, outside of the framework of Afropessimism, see Rozena Maart, 'Exordium: Writing and the Relation: From Textual Coloniality to South African Black Consciousness', in Monica Michlin and Jean-Paul Rocchi (eds.): Black Intersectionalities: A Critique for the $21^{\text {st }}$ Century (2013: 21-33). 
all roads of thought lead back to the Greek and Latin languages. Oddly enough, as my colleague Mogobe Ramose reflected in the 2019 Decolonial Summer School at the University of South Africa, if one were to go to Athens today and head to what we would consider its universities, we would have to look for the

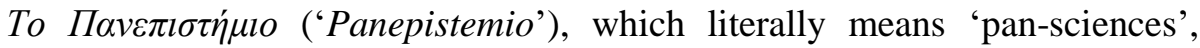
though some might interpret it as 'pan-knowledges'. We already see here a model that is very different from the understanding of places of learning we have acquired from histories of colonisation and imperialism. Such a history demands only one prevailing, whereas the notion of pan-knowledges and pansciences suggests a meeting of different ways of thinking and doing thinking. It requires a commitment not only to co-existence but also communicating - in other words, learning from each other. We could call this a community of learners. Thought of as a community of learners, this means that places of learning must think of students, professors, staff, visitors - anyone in its community - as interconnected and part of something ultimately greater than themselves. For instance, I begin my classes by asking students to define a professor. The students often offer hierarchical models that make professors seem like Moses at Mount Sinai with the sacred tablets. I then offer my two cents. A professor, as I see it, is someone who fell in love with learning and continued to learn. The learning over the years takes the form of research, but it is not limited to that. In short, a professor is an advanced student who has continued learning. A student, then, is simply a beginner or a person earlier in her educational journey. Some professors become jaded and forget what sparked their intellectual pursuits, but this does not change their status of being advanced students. And still there are others who may have entered the profession without any concern for learning but instead the narcissistic pursuit of 'prestige'. Even so, to get where they are required some kind of learning, which makes their advanced student status also evident. It does not follow that all students are good students in the sense of commitment to the pursuit of learning.

The crucial point is that this understanding of professors and students requires the virtue of humility. The reason is that no one comes to learning without different experiences to bring to the subject. Thus, an advanced learner could learn from the experiences of a student at a beginner stage. As well, a beginner student can learn not only from the advanced accumulation of knowledge of the advanced learner but also from the different experiences that the learner or professor bring to the subject. We could call this the relational and functional model of learning. From this point of view, learning is not 
something one carries as one would water in a vessel. It requires understanding even ourselves as open possibilities through which, in relationships with others, we discover - through active engagement - new things about ourselves, others, and the world in which we live9.

Some people discourage other people from changing when they seek an education. This is a silly path to take. Education, after all, requires growth, and how can one grow without changing? This brings us to an important element of places of learning. We have many names for them, but the one that prevails in the English language is 'schools'. As with the discussion of what is a professor, I begin courses with a conversation as well on what is a school, even during my years as a secondary school teacher in the mid-1980s.

Readers could imagine what my adolescent students' responses to that question were. Among them was, simply, "School sucks!" Others would say it's a place they were forced to attend. I would then offer some input. The origin of the word 'school' is the Greek word $\sigma \chi 0 \lambda \eta$ ('skhole'). It means leisure time. You could imagine their response. I would explain that it was not only Greekspeaking people but also many others from all over the world who realised the unusual circumstance of what is achieved in not having to spend all of one's waking life searching for food, water, shelter, and in addition, to avoid becoming other creatures' next meal. Freed now and then from exigency, our ancestors discovered they could devote their time to uniquely human things. Among those activities was the pursuit of knowledge. And this was acquired through the 'lecture', which is another word for $\sigma \chi 0 \lambda \eta$, and which would lead to our English word 'school'. In the ancient African language Mtw Ntr ('divine speech', spoken by the ancient peoples of Kmt/Egypt), for instance, the word for what we now call 'school' is $s b A$. That word also means 'student'. Relatedly what occurs in a $s b A$ is $s b A y t$, which means 'written teaching or instruction'. A connection here is also to the quality of instruction one hopes

9 These are ideas argued for, in one form or another, in the thought of many theorists. They are in Frantz Fanon's Les Damnés de la terre(1961) and Paulo Freire's Pedagogy of the Oppressed (1981). The specific forms offered here are what Jane Anna Gordon and I call 'the pedagogical imperative'. For related discussion also at work here, see Boaventura de Sousa Santos, The End of the Cognitive Empire: The Coming of Age of Epistemologies of the South (2018); Catherine Walsh, 'The Decolonial For: Resurgences, Shifts and Movements' (2018); Lewis R. Gordon, Freedom, Justice, and Decolonization (2021). 
will be manifested. SbAyt also means 'wise teachings'. It is an idea later transformed among Greek speaking students, who eventually changed the ' $b$ ' to ' $p h$ ', as they pronounced it with what was close to the English ' $f$ ', to give us sophia - namely, 'wisdom'.

In a way, understanding that school enables us to devote our time to uniquely human things makes the current divisions of learning institutions into the humanities, sciences, and professional schools both artificial and misleading. After all, every one of these is a uniquely human activity. Institutions of learning are, ultimately, the humanities. This is because everything that takes place in them - including activities such as sports, fraternities and sororities, political and other forms of clubs - are not only human but also what is involved in helping us learn to become more so. In other words, what many people discovered is that with leisure time, we can devote ourselves to becoming human. This idea of becoming human is paradoxical, since it requires many of us being human beings and actively becoming human beings. We could expand this idea beyond the mechanical understandings of learning to the larger one of cultivation and communication and the power that brings us together in what is called citizenship. In citizenship, we develop our ability to make things happen, which is what 'power' actually means. The growth occasioned by education, is also empowerment ${ }^{10}$.

Of course, this is not to say that these ideas are without need of critique. After all, who is afforded leisure time depends on the organisation of the society in which it is proffered. Many of the Greek-speaking people were organised into polities in which at times four-fifths of the population were enslaved for the luxury of others' leisure. In others, such as in ancient Axum, Kush and various periods of Kemet, either there was sufficient collective labour to facilitate shared leisure or at least smaller numbers of those on whose labours others depend. We need not romanticise the past to realise that human beings, as opposed to other animals, generally found time to do uniquely human things emerging from the cultivation of culture. I have been focusing on Greek etymologies because the context in which these reflections have come to print is a primarily English-speaking audience. We should remember, however, that Greek is actually a fairly recent language in the life of a species that is about 220000 years old. There are African language origins of many

${ }^{10}$ For elaboration, especially with regard to citizenship, see Lewis R. Gordon, 'Cities and Citizenship' (2017: 36-43). 
Greek and Latin words because of the obvious fact that African languages are older and the continent's northern shores are primarily of the Mediterranean ${ }^{11}$.

I have already shown a more ancient African origin of the word sophia. Another is the word 'power', whose etymological accounts often point to the Latin 'potis'. Yet if one were to dig deeper into the past, one would discover that that word in turn is from the Mtw Ntr word pHty, which refers to godlike or divine strength. Think of how today we perceived ultimate divinity as omnipotent. I could imagine the many insights on this idea that could be offered by many readers whose indigenous language is one other than English or any other European language. Indigenous Africans may find connections in their various languages connected to such insights ${ }^{12}$. Indigenous peoples of Abya Yala (the Kuna-Tule people's name for what is now called 'the Americas') may offer other elaborations as their diversion from communication with peoples of Africa, Asia, and Europe may be more ancient. Still, the commitment to keep learning to learn is, we should remember, an endless task, as those who have taken up those other elaborations attest ${ }^{13}$.

\section{Decolonising and the Decolonial Foci on Institutions of Learning: Racism}

Let us now turn to another critical consideration of decolonising and decolonial foci on institutions of learning: racism. It is not only that institutions of learning during colonial times drew sustenance from practices of colonisation but that

${ }^{11}$ See Cheikh Anta Diop's Parenté Génétique de L'Égyptien Pharaonique et des Langues Negro-Africaines (1977) and Cheikh Anta Diop: L'homme et l'oeuvres (2003); Charles Finch, III, Echoes of the Old Darkland (1991); Gerald Massey, The Natural Genesis ([1883] 1998, and Anténor Firmin, De l'égalité des races humaines: anthropologie positive (1885).

12 See, for instance, Nkiru Uwechia Nzegwu, Family Matters: Feminist Concepts in African Philosophy of Culture (2006); His Majesty Nnaemeka Alfred Ugochukwu Achebe: A Ten-Year Milestone (2013); Oyèrónké Oyewùmí, What Gender is Motherhood? Changing Yorùbá Ideals of Power, Procreation, and Identity in the Age of Modernity (2015).

${ }^{13}$ See, for example, Boaventura de Sousa Santos, Epistemologies of the South: Justice against Epistemicide (2014) and Julia Suàrez-Krabbe, Race, Rights and Rebels: Alternatives beyond Human Rights and Development (2015). 
they also produced an understanding of who could learn and who supposedly could not that was blatantly racist. A difficulty with talking about racism is that we are taught, in racist societies, from birth to grave, to pretend it either does not exist or is always irrelevant. It would take too much time here to address the details of why this is so. Among the many reasons is the focus on racists instead of racism. In other words, more people are worried these days about being called or identified as racists than about the ongoing effects of racial inequality and the institutions that foster it. Worried about being accused of being racist, the easiest path for them is to deny racism, as though racists and racism must be identical. This may seem counter-intuitive, but the logic of being racist and that of racism are not the same.

Look at it this way: a racist is an individual with racist beliefs; that person could believe that her race is superior to other races, or she may consider her race inferior to other races and thus support the other races. Now, imagine that person has very limited power. In other words, her racist beliefs will have no impact on the world beyond the insult she may directly unleash upon groups she dislikes. For the most part, her being a racist is irrelevant to the lives of the people she hates - unless, of course, she has the power of a goddess. Now, consider a society in which no individual people believe in the superiority or inferiority of their race but all the institutions are designed to assure that a specific group's race is placed at an advantage over others or that a particular race or group of races is at a disadvantage. Let us imagine that the society does not question its legitimacy. This would affect how evidence is interpreted in that society. What could their advantages be but evidence of one group's supposed excellence and others' limitations?

Racism is the institutional investment of power in one race of people over others. This requires, as well, the institutional divestment of power from certain groups. In other words, racism depends on empowering one race and disempowering others. To support racism, rationalisations of how such institutions function becomes necessary. I call these 'pleasing falsehoods' Of course, where there are pleasing falsehoods (such as the non-humanity of black and indigenous peoples), there are also displeasing truths (such as black and indigenous peoples are human beings living under institutional conditions

\footnotetext{
${ }^{14}$ See, for example, Lewis R. Gordon, Bad Faith and Antiblack Racism [1995)] (1999); Existentia Africana: Understanding Africana Existential Thought (2000); and, more recently, Freedom, Justice, and Decolonization (2021).
} 
of human degradation). Racism thus requires avoiding or hiding from the truth, which is the set of falsehoods on which racist societies rest. This is one of the reasons why disciplines whose purpose is to unveil such lies are often attacked in racist societies. I recall a debate I had with a black conservative nearly two decades ago in which my opponent argued that Black Studies should not be taught in American universities because it supposedly makes students 'angry'. (I am sure similar objections are made in other countries across the globe.) My response was at first cheeky: "And what's wrong with that?" But then I got to the central point. Many people think disciplines such as African Studies, Black Studies, Ethnic Studies, Women, Gender, and Sexuality Studies, and Indigenous Studies exist for people to see themselves in the curriculum. This is partially true; but there is an additional element. Without these disciplines, students often receive a very lopsided version of the world in which they live.

So much is kept out that what is left is, as dominant groups would have it, pretty cosy and sterile. That offers little, if any, room for critique of past governors, epistemological or otherwise, who persist and thus continue to rule. For example, whenever I teach Contemporary African Philosophy, students often notice something peculiar. Because that area of philosophy is not hegemonic, I must explain why it is philosophical, which means explaining what understanding philosophy is, with which the class would be working. This involves being accountable for everything that is taught. It is similar to what I have already mentioned about education, schooling, and what it means to be a professor. The students learn not only about philosophical movements outside of the European traditions of analytical and Eurocontinental practitioners but also about elements of the European tradition often taken for granted and thus offered without accountability. The students tend to get appropriately angry at the realisation of how miseducated they are in so-called generic or 'pure' philosophy classes. Their anger is not against what is called 'Western philosophy'. Their anger is against not being offered a fuller picture of what philosophy proposes. They become upset because they seek education instead of being spoon-fed a particular worldview cloaks of avowed universality. Now, an excuse often given when they return to their other professors is that African, Native American, Asian, and many other philosophical offerings are not those instructors' areas of specialisation. The problem there is that the students are not asking for their professors to be experts in those areas but instead - and at least - for them to exemplify the virtue of a commitment to continued learning. Gaining some competence could 
go a long way. Jane Anna Gordon and I call this the pedagogical imperative ${ }^{15}$. It means to continue learning while one teaches. When I teach Contemporary African Philosophy, I do not only place that subject in conversation with European philosophy but also put it in conversation with what is offered across the globe. It is clear to the students that the incarnation of the course they encounter is but one and that it will change over time as I continue to learn. Why not receive something similar in their other classes?

When I teach existentialism, I examine problems of existence as posed and addressed across the globe - among African, Asian, Australasian, and Indigenous thinkers of Abya Yala and existential thinkers to their north. Students leave such courses realising that all people think and offer ideas for our common humanity's effort to grow. Anger, where it comes from a desire to learn, is actually, as Frantz Fanon showed in some of his psychiatric and political writings, healthy ${ }^{16}$. It is different from the anger premised upon rage against others. Put differently, the first kind of anger is ironically an expression of virtue. It is the same kind that is animated from being moved against injustice. The second kind is a vice. It is vicious because it is motivated against the dignity and empowerment of others. Racism is connected to the second kind. Now, although I am talking about racism, for the sake of time and space, I am going to shift to some critical remarks about how we engage in such talk. Many of us - I say 'us' because racism is a global phenomenon - are accustomed to talking about concepts and ideas in ways that separate their connection to what makes them possible. Yet, if human beings are creatures born of relationships, then it follows that efforts to disempower us are connected to blocking our capacity for growth through such relationships.

${ }^{15}$ See Lewis R. Gordon and Jane Anna Gordon, 'On Working through a Most Difficult Terrain: Introducing A Companion to African-American Studies', in A Companion to African-American Studies (2006: xx - xxxv); Jane Anna Gordon, 'Beyond Anti-Elitism: Black Studies and the Pedagogical Imperative' (2010:1 - 16); Lewis R. Gordon, 'A Pedagogical Imperative of Pedagogical Imperatives' (2010: 27 - 35). For related discussion of critical pedagogy in the context of critical thought in contemporary feminist theory, see Rozena Maart, 'Race and Pedagogical Practices: When Race Takes Center Stage in Philosophy' (2014:205 - 220).

${ }^{16}$ See Frantz Fanon, Alienation and Freedom, edited and compiled by Jean Khalfa and Robert J. C. Young (2018). 
This is one of the harms of racism, but racism never manifests this by itself.

I have over the years taught a semester-long seminar called 'Race in the Formation of the Human Sciences'. Our readings during the third week of that course focus on writings from François Bernier in the 17th century through to Immanuel Kant in the 18th century and then all the way through to Francis Galton, the eugenicist, in the 19th century. The students are often shocked at the racism they see at work in how many of the human sciences were formed. Much of this is because they are used to studying their intellectual heroes as gods instead of as human beings, with all the imperfections of such. It is a form of theodicy that permeates much thinking, not only in the academy but also in most people's relationship to society.

Theodicy is the kind of rationalisation in which one attempts to preserve the goodness of an omnipotent and omniscient being in a world marked by injustice. If such a being or Being is good and just, why does it not intervene? Why does it let terrible things happen? There are many classic responses from antiquity through to the Middle Ages to recent times - see the African philosopher St. Augustine for some examples, the German 17th century philosopher (and many things else) Gottfried Leibniz and the recently late Ghanaian philosopher Kwame Gyekye for other critiques - in which two responses dominate: (1) human finitude limits understanding the omnipotent and omniscient being or Being's ultimate plan; and (2) the love from such a being or Being entailing not standing in the way of human freedom which messes things up ${ }^{17}$.

I won't address the fallacies of (1) and (2) here ${ }^{18}$. What is crucial for the purposes of this discussion is the observation that theodicean

${ }^{17}$ See, for example, St. Augustine, The City of God (1950); Gottfried Wilhelm Leibniz, Theodicy (1952); and Kwame Gyekye, An Essay on African Philosophical Thought: The Akan Conceptual Scheme (1987). John Hicks's Evil and the God of Love (1978); William R. Jones's, Is God a White Racist: A Preamble to Black Theology (1997); Sherman A. Jackson, Islam and Black Suffering (2009); and Anthony B. Pinn, Why, Lord? Suffering and Evil in Black Theology (1999). See also Lewis R. Gordon, An Introduction to Africana Philosophy (2008) and Freedom, Justice, and Decolonization (2021).

${ }^{18}$ Gyekye offers an excellent critique in An Essay on African Philosophical Thought (1987). See also Hicks's Evil and the God of Love (1978). I offer critical discussion in many contexts, including Freedom, Justice, and 
rationalisations take the prized being/Being off the hook. If we secularise it, we would see the same kinds of rationalisation at work in the defence of, say, South Africa, the United States of America (USA), and their Constitutions to models of knowledge through which the degradations of excluded peoples are cultivated $^{19}$. When it comes to the study of the writings of canonical thinkers, I call this theodicy of the text, where they are treated like gods who have produced perfect works. Yes, it is a form of idolatry. We should bear in mind that this theodicy is also at work in the contrary position, where such authors are demonised.

In both cases, the result is the erasure of their humanity. This is not to excuse those canonical European thinkers. It is to point out that it is our responsibility to address the imperfections of thought - in a word, to really read what any author has written - and offer better alternatives. When we move to the seemingly nonracist elements of their thought, we do find some elements on which ironically their racist elements depend. Here are some examples. First, there is an obsession with the 'origins' of humankind in a way that leads to considering other groups of human beings as 'deviations' from those origins. Second, there is the presumption that the 'original' must be 'pure'. Third, there is concern with reproduction - or repetition - as law. All this is abstract, but much of it is familiar. The first often presumes that the person doing the theorising belongs to the original group. Thus, Kant argued that human beings must have evolved in geographical and climactic conditions similar to the German/Prussian world of his day. Second, many of those thinkers presumed that diversity was deviation and origins were pure. As many of us know today, it turns out that at least biological origins point to places of maximum genetic diversity. And the obsession with reproduction for those thinkers was premised on the idea of male sources of progeny. Thus, control of female reproductive behaviour was central, and this led to an obsession with blocking certain males,

Decolonization (2021) and, with Jane Anna Gordon, Of Divine Warning: Reading Disaster in the Modern Age (2009).

${ }^{19}$ In South Africa and the USA, constitutionalism has become forms of idolatry through which the larger picture of their constitutions often stopping short, where the lives of the damned of the earth are concerned, are often ignored. I discuss this problem in Freedom, Justice, and Decolonization (2021); see also Rozena Maart, 'Philosophy Born of Massacres. Marikana, the Theatre of Cruelty: The Killing of the "kaffir"" (2014). 
now racialised, from sexual reproduction ${ }^{20}$.

Much of this comes along with a long history that, again, I cannot spell out here for sake of space but have done so elsewhere in my books and articles. The short of it is the long history of how Christianity is linked to those ways of thinking about origins and purity and how the rise of global capitalism during the period of such reflections required a group of people who were linked to it as its benefactors ${ }^{21}$. Placing all these things together, one not only has the notion of white supremacy but also the psychological and sociological elements that support it. All this means, as I hope the readers will be realising, that addressing racism is complicated because it is connected to so many elements of the world in which we now live.

There are scholars and theorists today who call this 'intersectional' 22 . I prefer to call it 'multidimensional'. Both are connected to a basic insight. No human being is one-dimensional. In fact, one-dimensionality is one of the goals of racism. It is the oversimplification of what people are and how people live. Has anyone ever seen a 'race' walking? How about a 'gender'? A 'sexuality'? A 'class'? The list goes on. These abstractions eliminate other elements of people to achieve a 'pure essence' of what is sought. That is why so many make the mistake of looking for pure origins. They don't realise that the emergence of human beings is so profoundly existential that there is always 'other-than' added to any appeal to a singular element to which human beings supposedly conform or belong. Realising this, we should instead move from elimination to

${ }^{20}$ For a compilation of the relevant literature, from Bernier through to Galton, see Robert Bernasconi and Tommy Lott (eds.), The Idea of Race (2000).

${ }^{21}$ Among the books in which I discuss the formation of white supremacy and anti-black racism is Fear of Black Consciousness (2021).

22 See, for example, Kimberlé Crenshaw, 'Mapping the Margins: Intersectionality, Identity Politics, and Violence Against Women of Colour' (1991: 1241 - 1299) and, interviewed by Bim Adewunmi, 'Kimberlé Crenshaw on Intersectionality: 'I wanted to come up with an everyday metaphor that anyone could use' (2014); and Evelyn Simien and Ange-Marie Hancock, 'Intersectionality Research' (2011: 185 - 243). For elaboration in ways connecting to my point about multidimensionality, see Rozena Maart, 'Exordium: Writing and the Relation: From Textual Coloniality to South African Black Consciousness' and Lewis R. Gordon, Fear of Black Consciousness (2021). 
connections. This is another way of using the grand term 'relationality'. So, let us do that. Let us look at various ways in which human beings attempt to force other human beings outside of relationality with the consequence of disempowerment ${ }^{23}$.

\section{Disempowerment and Invisibility}

For now, for the purpose of brevity, I will call this disempowerment 'oppression' and place 'invisibility' into the long list of its many consequences. The first disconnection is to reject the right to exist numerically or quantitatively. This one tags onto race immediately. Where there is racism, there is always the claim that there are too many members of the rejected group around. Although any group could be made into such - as we see happening right now with the hatred being fomented against immigrants in many countries across the globe - the historic signifier of this one is black people. There are supposedly always too many black people around, even in countries where black people are actually a near-negligible number of the population. This is why many institutions think they achieve diversity by having one black person in any given context. One. This might be understandable in some Scandinavian countries, but, as many know, such an attitude develops in professional institutions in countries such as Brazil and South Africa where the black population far exceeds their representation in institutions of power. To make the inclusion of one count as diversification is absurd. That makes blackness potent stuff. It makes such people exponential. The second is temporal. This is a tricky one. It is linked to how we think of what it means to be 'modern'. The word 'modern' is from the Latin modo (which means 'just now'). How do you know 'now' except through anticipation of the future? If one does not enter the future, then one's 'now' belongs to a past. But which past? If it is not that one that immediately precedes us - because of being linked to where we are going - then it must be to one that ceased to go anywhere. Thus, in effect, to be modern is to belong to where humanity is going, which means to be linked to the future, which retroactively legitimates one's now and, through that, one's past. Here, disempowerment becomes linked to land. In settler colonial societies, the settlers conclude that indigenous peoples belong

\footnotetext{
${ }^{23}$ I offer here a summary of the discussion of these features elaborated in Fear of Black Consciousness (2022).
} 
to the past since the future is supposedly 'settled' for the settlers whose relationship to land is premised on its transformation into 'property'.

Most (if not all) Indigenous people's conceptions of land are as many Indigenous scholars across the globe have argued, based on understanding at least its relationship to life in which people are more like custodians instead of property owners. The idea that those linked to land in this way leads to the construction of 'primitives' and other notions of people who supposedly do not belong to the future. This is what many Indigenous people fight against across the globe. From the perspective of settlers, such people are not legitimate, even 'now'. What do we call someone who belongs to the past but stands before us in the present? The word in English is 'ghost'. Such people are thus treated as 'haunting' the present. Think here of the tendency many non-indigenous people have of leaping quickly to spiritual concepts and metaphors whenever Indigenous people are mentioned. In Africa and Australia, where Indigenous people are also black, one notices oscillation between quantity (race) and temporality (haunting) depending on the focus. When many non-Africans discuss Africans as 'indigenous', spiritual language is soon to follow.

The third regards speech. This one is peculiarly gendered in European and Asian societies. It is there in ancient myths of mute women. If one were to peruse women's writings, one would notice the large presence of titles with the word 'voice' in them. Here is a short list: Anna Julia Cooper (1892), A Voice from the South; Carol Gilligan (1982), In a Different Voice; Michelle Walker (1993), 'Silence and Reason: Woman's Voice in Philosophy'; Kathryn Lasky's (2005) biography of African American poet Phillis Wheatley, A Voice of Her Own; Mike River's (2005) Listen to Her Voice: Women in the Hebrew Bible; Judy Yung's (1999) documentary history of Chinese American women, Unbound Voices; Emily Honig and Gail Hershatter's (1988) book on Chinese women in the 1980s, Personal Voices; the subtitle of Xinran's (2003), The Good Women of China is Hidden Voices.

I refer to these authors because they are in the European and Asian contexts and their extension in their colonies. The crucial point here is that speech is a required element for political participation. To appear politically to have power - is to have a voice. But what this means is not simply that one speaks but also that one is either not heard or heard without being listened to. If one is not heard, then one's mouth is moving but the effect is silence. These are expressions of a basic fact. Disempowerment demands being politically mute. The final one is epistemological. Epistemology refers to theories of 
knowledge. I will not belabour this one since it is clearly a consequence of the other three: If one should not exist, if one does not belong to the future, and if one is voiceless, then what one offers epistemologically becomes void. The consequence is what I call epistemic closure ${ }^{24}$. This means that there is a form of invisibility that occurs ironically when one is 'seen' because one's appearance is illicit. This means that to see people in these groups is to see all that needs to be seen; there is supposedly nothing more to know. Learning is shut down. There is no question. There is no inquiry. The door is epistemologically closed.

It should be clear that any group could be placed into these four categories depending upon the conditions placed on them. And this is the point. All of these are human-created forms of disempowerment. It is thus the responsibility of the human world to fix them. It is also crucial to bear in mind that this typography is not exhaustive. For instance, I did not mention here how disability is often equated with inability. 'Disabled' and 'unable' are different considerations, and there are many forms of epistemic closure that elide lived reality and the range of what is at work in the lives of those labelled 'disabled'. We come, then, to my concluding - and I must stress non-exhaustive - remarks. There is much more that I can say on what is at work with all of these, but the main consideration I would like to make connects to the idea of political responsibility.

These are all human manifestations of power. Power, I should like to reiterate, is the ability to make things happen. We could use that ability to enable others to make things happen. Or we can use our ability to block others from being able to do the same. This is what disempowerment means.

\section{Towards a Conclusion}

Too many of us want to restrict our analyses of racism, sexism, homophobia, class inequalities, and settler colonisation to moral forms of discourse. In doing so, we individualise what are in fact political issues. Why does this pose a problem? If such problems really depend on individuals as individuals, such individuals would have to be gods if they held such power to change the world. With morality, one can point to who is responsible and who is not. Political

${ }^{24}$ For elaboration, see, for example, Lewis R. Gordon, Existentia Africana (2000: 65, 88-90, 151-158, 162). 
responsibility, however, is very different. First, it is always about us. This is because the jurisdiction of political power is over all within its jurisdiction. Second, because it applies to all within its domain, it pertains to those who are no longer here and those to come into its ambit. This means, then, that it applies as well to the anonymous. Third, unlike moral responsibility, where one could be innocent or guilty, such a notion is irrelevant when it comes to political responsibility. What matters is that one is a member of the polity. This is why it does not work to protest that one did not vote for those in power.

Everyone will bear the burden of the actions of their government and those entrusted with its function. It also explains why language of purging oneself of coloniality, while commendable, achieves very little, if anything, politically ${ }^{25}$. Take, for example, debates on reparations. When people discuss this in the USA as what white people owe black people, they miss the point. Black people are, after all, members of that society. This means those historically and presently harmed and everyone else will share its obligations - including its penalties. Whose tax revenue and other resources would such compensation come from? This is why white people who go to the USA and reject reparations on the grounds of not being the historical white people involved in the enslavement of African people miss the point. They share with recent immigrant black people the same burden. Becoming a member of a society entails also taking on its debts. This applies as well to the responsibility for the unfortunate, dehumanising activities happening at borders and other areas of the USA and similar countries across the globe. No society lasts forever; no government is 'on top' forever. At some point, its people will be held accountable.

The German philosopher Karl Jaspers, who lived through Nazi Germany and courageously fought against the machinations of that government and his fellow citizens, had a chilling observation on what follows their being vanquished: Has such a society behaved in a way deserving of mercy $?^{26}$ 'But what can $I$ do?' each reader may be tempted to ask. Or worse, 'There is nothing I can do'. On this score, there is much to be learned from so many who faced what in their times seemed impossible. The ancestors of

${ }^{25}$ For elaboration, see Freedom, Justice, and Decolonization (2021); and Fear of Black Consciousness (2021). And for similar discussion, see Iris Marion Young, 'Responsibility and Global Labor Justice' (2004: 365-88).

${ }^{26}$ Karl Jaspers, The Question of German Guilt (2000). 
Indigenous people faced an eliminated future. So, too, did many enslaved people. The list can go on. All the circumstances around them offered one message: any effort to alleviate their condition will fail. So, we should ask, why did they act? We know they acted, because if they had not, many of us their descendants among the damned of the earth - would not be here. They acted without forecast. They acted without guarantee. They acted, however, out of commitment. This many of them were able to do because they understood the importance of the relationship of ancestors to descendants; they knew, in other words, that their actions were not about them but about $u s$ as understood as generations over all time, of the witnesses gone and those to come. We have an opportunity, then, in places of learning, and the broader 'here' beyond them. This involves examining the vices of degradation and antitruths or pleasing falsehoods that challenge communication and our imaginative capacity to build institutions of integrity and human flourishing. It also involves thinking anew about questions of what it means to be human, free, and reasonable in an age in which proverbially all is at stake. Eradicating the 'what's in it for $m e$ ' mentality would open the door to what is to be done to build better places of learning and, by extension, better societies. These debates on decolonisation and decoloniality may not be original in form, but in content they do expand the scope of what all of us should consider. A question we could ask ourselves, through such action, is whether, politically considered, our descendants' response would be, upon looking back upon us, 'We are so fortunate they acted' instead of, 'Why, O why, did they not act?'

\section{References}

Ahmad, A. 1992. In Theory: Classes, Nations, and Literatures. London, UK: Verso.

Ahmed, K. 2019. On Black Pain/ Black Liberation and the Rise of Fallism. Black Issues in Philosophy 19 March. Available at:

https://blog.apaonline.org/2019/03/19/on-black-pain-black-liberationand-the-rise-of-fallism/

Ahmed, A.K. 2019. The Rise of Fallism: \#RhodesMustFall and the Movement to Decolonize the University. New York: Columbia University Dissertation. Available at: https://academiccommons.columbia.edu/doi/10.7916/d8-n7n3-e372 
Thoughts on Decolonisation, Racism, and Challenges of Citizenship

(Accessed on 18 September 2020.)

Amin, S. 1988. L'eurocentrisme: Critique d'une idéologie. Paris: AnthroposEconomica.

Augustine, St. 1950. The City of God. Doas, M. (trans.). New York: Modern Library.

Bernasconi, R. \& T. Lott (eds.). 2000. The Idea of Race. Indianapolis: Hackett Publishers.

Butler, J. 1990. Gender Trouble: Feminism and the Subversion of Identity. New York: Routledge.

Caws, P. 1997. Structuralism: A Philosophy for the Human Sciences. Amherst,

NY: Humanity Books.

Cazenave, N.A. 2018. Killing African Americans: Police Vigilante Violence as a Racial Control Mechanism. New York: Routledge.

Cooper, A.J. 1892. A Voice from the South. Xenia, OH: The Alding Printing House.

Crenshaw, K. 1991. Mapping the Margins: Intersectionality, Identity Politics, and Violence against Women of Color. Stanford Law Review 43, July: 1241 - 1299. http://dx.doi.org/10.2307/1229039.

Crenshaw, K. 2014. Kimberlé Crenshaw on Intersectionality: 'I wanted to come up with an everyday metaphor that anyone could use'. Interviewed by Bim Adewunmi. The New Statesman 2 April:

http://www.newstatesman.com/lifestyle/2014/04/kimberl-crenshawintersectionality-i-wanted-come-everyday-metaphor-anyone-could

Dey, S.D. (ed.). 2018. Different Spaces, Different Voices: A Rendezvous with Decoloniality. Mumbai, India: Becomeshakespear.com.

Diop, C.A. 1977. Parenté Génétique de L'Égyptien Pharaonique et des Langues Negro-Africaines. Ifan-Dakar: Nouvelles Éditions Africaines.

Diop, C.A. 2003. Cheikh Anta Diop: L'homme et l'oeuvres. Paris: Présence Africaine.

Dussel, E. 1996. The Underside of Modernity: Apel, Ricoeur, Rorty, Taylor, and the Philosophy of Liberation. Mendieta, E. (trans.). Atlantic Highlands, N.J.: Humanities Press.

Dussel, E. 2013. Anti-Cartesian Meditations: On the Origins of the Philosophical Anti-Discourse of Modernity. Human Architecture XI,1, Fall: 25 $-29$.

Fanon, F. 1952. Peau noire, masques blancs. Paris: Éditions du Seuil.

Fanon, F. [1961] 1991. Les Damnés de la terre. Paris: François Maspero 
éditeur S.A.R.L./ Paris: Éditions Gallimard.

Fanon, F. 2018. Alienation and Freedom. Khalfa, J. \& R.J.C. Young (eds.).

Corcoran, S. (trans.). London: Bloomsbury Academic.

Finch, C.S. III 1991. Echoes of the Old Darkland: Themes from the African Eden. Decatur, GA: Khenti, Inc.

Firmin, A. 1885. De l'égalité des races humaines: anthropologie positive. Paris: Librairie Cotillon.

Freire, P. 1981. Pedagogy of the Oppressed. Bergman Ramos, M. (trans.). New York: Continuum.

Gilligan, C. 1982. In a Different Voice: Psychological Theory and Women's Development. Cambridge, MA: Harvard University Press.

Gordon, J.A. 2009. Of Divine Warning: Reading Disaster in the Modern Age. New York: Routledge.

Gordon, J.A. 2010. Beyond Anti-Elitism: Black Studies and the Pedagogical Imperative. The Review of Education, Pedagogy, and Cultural Studies 32,

2: 1 - 16. https://doi.org/10.1080/10714411003799033

Gordon, J.A. 2014. Creolizing Political Theory: Reading Rousseau through Fanon. New York: Fordham University Press.

https://doi.org/10.5422/fordham/9780823254811.001.0001

Gordon, J.A. \& L.R. Gordon 2006. On Working through a Most Difficult Terrain: Introducing A Companion to African-American Studies. In Gordon, J.A. \& L.R. Gordon (eds.): A Companion to African-American Studies. Malden, MA: Blackwell.

https://doi.org/10.1111/b.9780631235163.2005.00003.x

Gordon, L.R. [1995] 1999. Bad Faith and Antiblack Racism. Amherst, NY: Humanity Books.

Gordon, L.R. 1997. Her Majesty's Other Children: Sketches of Racism from a Neo-colonial Age. Lanham, MD: Rowman \& Littlefield.

Gordon, L.R. 2000. Existentia Africana: Understanding Africana Existential Thought. New York: Routledge.

Gordon, L.R. 2006. Disciplinary Decadence: Living Thought in Trying Times. New York: Routledge.

Gordon, L.R. 2008. An Introduction to Africana Philosophy. Cambridge, UK:

Cambridge University Press.

https://doi.org/10.1017/CBO9780511800726

Gordon, L.R. 2010. A Pedagogical Imperative of Pedagogical Imperatives. Thresholds in Education XXXVI, 1 \& 2: 27 - 35. 
Gordon, L.R. 2012. Essentialist Anti-Essentialism, with Considerations from Other Sides of Modernity. Quaderna: A Multilingual and Transdisciplinary Journal 1.

http://quaderna.org/wp-content/uploads/2012/09/Gordon-essentialistanti-essentialism.pdf

Gordon, L.R. 2017. Cities and Citizenship. The Kettering Review 34, 1, Fall: $36-43$.

Gordon, L.R. 2021. Freedom, Justice, and Decolonization. New York: Routledge. https://doi.org/10.4324/9781003112594

Gordon, L.R. [2022.] Fear of Black Consciousness. New York: Farrar, Straus and Giroux; London: Penguin Press. (forthcoming.)

Grosfoguel, R. 2012. Decolonizing Western Uni-versalisms: Decolonial Pluriversalism from Aimé Césaire to the Zapatistas. Transmodernity 1, 3, Spring: 88 - 104.

Grosfoguel, R. 2013. The Structure of Knowledge in Westernized Universities:

Epistemic Genocides/ Epistemicides and the Four Genocides of the Long $16^{\text {th }}$ Century. Human Architecture XI, 1, Fall: 73 - 90.

Gyekye, K. 1987. An Essay on African Philosophical Thought: The Akan Conceptual Scheme. Revised Edition. Philadelphia: Temple University Press.

Henry, P. 2000. Caliban's Reason: Introducing Afro-Caribbean Philosophy. New York: Routledge.

Henry, P. 2007. C.L.R. James and the Orthodoxies of John McClendon and David Scott: A Review Essay. The C.L.R. James Journal 13, 1: 285 - 286. https://doi.org/10.5840/clrjames200713120

Henry, P. 2016. Africana Phenomenology: Its Philosophical Implications. In Gordon, J.A., L.R. Gordon, P. Henry, A. Kamugisha \& N. Roberts (eds.): Journeys in Caribbean Thought: The Paget Henry Reader. London, UK: Rowman \& Littlefield International.

Hicks, J. 1978. Evil and the God of Love. Revised Edition. New York: Harper \& Row.

Honig, E. \& G. Hershatter 1988. Personal Voices: Chinese Women in the 1980's. Palo Alto: Stanford University Press.

Jackson, S.A. 2009. Islam and Black Suffering. New York: Oxford University Press.

Jaspers, K. 2000. The Question of German Guilt. Ashton, E.B. (trans.). New York: Fordham University Press. 
Jones, W.R. 1997. Is God a White Racist? A Preamble to Black Theology. $2^{\text {nd }}$ Edition. Boston, MA: Beacon Press.

Lasky, K. 2005. A Voice of Her Own: The Story of Phillis Wheatley, Slave Poet. Somerville, MA: Candlewick.

Leibniz, G.W. 1952. Theodicy. Huggard. E.M. (trans.). New Haven: Yale University Press.

Lugones, M.L. 2010. Towards a Decolonial Feminism. Hypatia 25, 4, Fall: 742 $-759$.

Lugones, M.L. 2008. The Coloniality of Gender. World Knowledges Otherwise 2, 2: $1-17$.

Maart, R. 2013. Exordium: Writing and the Relation: From Textual Coloniality to South African Black Consciousness. In Michlin, M. \& J-P Rocchi (eds.): Black Intersectionalities: A Critique for the $21^{\text {st }}$ Century. Liverpool: Liverpool University Press.

https://doi.org/10.5949/liverpool/9781846319389.003.0002

Maart, R. 2014. Philosophy Born of Massacres. Marikana, the Theatre of Cruelty: The Killing of the 'Kaffir'. Acta Academia 46,4: 1 - 28. https://journals.ufs.ac.za/index.php/aa/article/view/1470/1447

Maart, R. 2014. Race and Pedagogical Practices: When Race Takes Center Stage in Philosophy. Hypatia 29, 1: 205 - 220.

https://doi.org/10.1111/hypa.12076

Maldonado-Torres, N. 2007. On the Coloniality of Being: Contributions to the Development of a Concept. Cultural Studies 21, 2 - 3: 240 - 270.

Maldonado-Torres, N. 2008. Against War: Views from the Underside of Modernity. Durham, NC: Duke University Press.

Maldonado-Torres, N. 2016. Outline of Ten Theses on Coloniality and Decoloniality. Fondation Frantz Fanon.

http://fondation-frantzfanon.com/outline-of-ten-theses-on-colonialityand-decoloniality/.

Massey, G.M. [1883] 1998. The Natural Genesis. Baltimore, MD: Black Classics Press.

Ndlovu-Gatsheni, S. 2013. Coloniality of Power in Postcolonial Africa: Myths of Decolonization. Dakar: CODESRIA.

Nelson, E. 2017. Chinese and Buddhist Philosophy in Early Twentieth-Century German Thought. London: Bloomsbury Academic.

Nishitani, K. [1961] 1982. Religion and Nothingness. Van Bragt, J. (trans.), Foreword by Ling, W.L. Berkeley, CA: University of California Press. 
Thoughts on Decolonisation, Racism, and Challenges of Citizenship

Nzegwu, N.U. 2006. Family Matters: Feminist Concepts in African Philosophy of Culture. Albany, NY: State University of New York Press. Nzegwu, N.U. 2013. His Majesty Nnaemeka Alfred Ugochukwu Achebe: A Ten-Year Milestone. Endicott, NY: African Resource Press.

Oyewùmí, O. 1997. The Invention of Women. Minneapolis: University of Minnesota Press.

Oyewùmí, O. 2015. What Gender is Motherhood? Changing Yorùbá Ideals of Power, Procreation, and Identity in the Age of Modernity. New York: Palgrave.

Pinn, A.B. 1999. Why, Lord? Suffering and Evil in Black Theology. New York: Continuum.

Quijano, A. 1995. Modernity, Identity, and Utopia in Latin America. In Arona, M., J. Beverly \& J. Oviedo (eds.): The Postmodernism Debate in Latin America. Durham, NC: Duke University.

Quijano, A. 2000. Coloniality of Power, Eurocentrism, and Latin America. Nepantla: Views from South 1,3: 533 - 580.

River, M. 2005. Listen to Her Voice: Women in the Hebrew Bible. Vancouver, Canada: Chronicle Books.

Silverstein, M.S. (ed.). 2013. In Her Voice: Women Directors Talk. Women Hollywood. https://womenandhollywood.com/

Sousa Santos, B. de. 2014. Epistemologies of the South: Justice against Epistemicide. New York: Routledge.

https://doi.org/10.4324/9781315634876

Sousa Santos, B. de. 2018. The End of the Cognitive Empire: The Coming of Age of Epistemologies of the South. Durham: Duke University Press.

https://doi.org/10.1215/9781478002000

Simien, E. \& A-M. Hancock 2011. Intersectionality Research. Political Research Quarterly 64, 1 March: 185 - 243.

https://doi.org/10.1177/1065912910393647

Silverstein, M. 2013. In Her Voice: Women Directors Talk Directing. Los Angeles: Women and Hollywood.

Suàrez-Krabbe, J. 2015. Race, Rights and Rebels: Alternatives Beyond Human Rights and Development. London, UK: Rowman \& Littlefield International.

Tillotson, M. 2011. Invisible Jim Crow: Contemporary Ideological Threats to the Internal Security of African Americans. Trenton, NJ: Africa World Press. 
Walker, M. 1993. Silence and Reason: Woman's Voice in Philosophy. Australasian Journal of Philosophy 71, 4: 400 - 424. https://doi.org/10.1080/00048409312345412

Walsh, C. 2018. The Decolonial For: Resurgences, Shifts, and Movements. In Mignolo, W. \& C. Walsh (eds.): On Decoloniality: Concepts, Analytics, Praxis. Durham: Duke University Press. Available at: https://www.dukeupress.edu/Assets/PubMaterials/978-0-8223-71090_601.pdf

Xinran 2003. The Good Women of China: Hidden Voices. New York: Anchor Books.

Young, I.M. 2004. Responsibility and Global Labor Justice. The Journal of Political Philosophy 12, 4: 365 - 388.

https://doi.org/10.1111/j.1467-9760.2004.00205.x

Yung, J. 1999. Unbound Voices: A Documentary History of Chinese Women in San Francisco. Berkeley, CA: University of California Press. https://doi.org/10.1525/9780520922877

Lewis R. Gordon Professor and Department Head Philosophy University of Connecticut, STORRS Honorary Professor at the University formerly known as Rhodes South Africa and Visiting Professor at the University of Johannesburg lewis.gordon@uconn.edu 